\title{
Effect of Building Information Modeling (BIM) on reduced construction time-costs: a case study
}

\author{
Moh Nur Sholeh ${ }^{1 *}$, Shifa Fauziyah ${ }^{1}$, Riqi Radian Khasani ${ }^{2}$ \\ ${ }^{1}$ Civil and Planning Department, Vocational School, Diponegoro University, Semarang 50275, \\ Indonesia \\ ${ }^{2}$ Civil Department, Faculty of Engineering, Diponegoro University, Semarang 50275, Indonesia
}

\begin{abstract}
Building Information Modeling (BIM) is an interesting study to be explored by technological developments. Especially with the Covid-19 pandemic, construction actors are encouraged to work according to the applicable protocol. BIM as integrated tool for managing projects from the beginning to the end of the work. On one side the classic problems of construction projects are high costs, late time, and quality that is not according to specifications. The purpose of this study is to analyze the effect of the use of BIM in construction projects on time and cost. A case study was carried out on a construction project that had implemented BIM. The results showed the use of BIM could cut time by $50 \%$ faster and reduce costs by $52.36 \%$. This time and cost-effectiveness are caused by the number of workers needed and the reduced duration so that it has an impact on fundin.
\end{abstract}

\section{Introduction}

Building Information Modeling (BIM) has been developed into a modern technology that helps work integration in the construction industry. Research on BIM mapping that results in the extent of knowledge about BIM and the potential integration of the BIM platform will be developed[1]. The development of BIM to green buildings has also been carried out with a series of studies that direct this research very interesting[2]. BIM has been developed into other studies such as construction supply chains[3, 4]. Besides, BIM has also been developed into integration with the Geographic Information System (GIS) to map geographic conditions in construction[5 - 7].

BIM's current challenge is how to reduce costs, improve quality, and speed up project time together. As it is known that one of the problems in construction projects is high costs and difficult to control. Research in Singapore obtained data from a random sample survey of cost surges that were valued at more than US\$ 5 million[8]. BIM research has also been carried out in Malaysia to determine its effect on time and cost[9]. Indonesia as a developing country also has a similar problem in time efficiency and financing construction. So, time and cost reduction approach with BIM is one interesting way to be analyzed.

The purpose of this study is to analyze the correlation between BIM expectations and the time-cost of construction projects. Delays are analyzed from the project life cycle caused by

* Corresponding author: mohnursholeh@live.undip.ac.id 
unskilled workers, incorrect design, material delays, incorrect work, and miscommunication[10, 11]. Factors causing the construction cost overruns in Indonesia are material inflation costs, accurate quantity take-off, and experience of project type[12]. These cost overruns are affected by project delays. Construction project costs consist of direct and indirect costs[13]. Direct costs are costs that can be separated and recognized directly used to produce a unit of output, while indirect costs are joint costs or overhead costs for all units of output produced[14]. In some studies, the analysis is more on indirect costs to anticipate project management.

\section{Methodology}

This study identifies differences in the use of the conventional BIM method which is currently still used by Indonesian construction stakeholders. This study compares BIM with conventional methods using three methods: questionnaire, interview, and case study. Questionnaire method to find out the comparison between BIM and conventional methods in the company. Respondents were asked whether the BIM method provided benefits to the company. Besides, the question in-depth to find out the advantages and disadvantages of BIM. Interviews with respondents were used to find out the direct application of the BIM method in the field and a comparison of case studies used to determine the difference in the effect of construction costs.

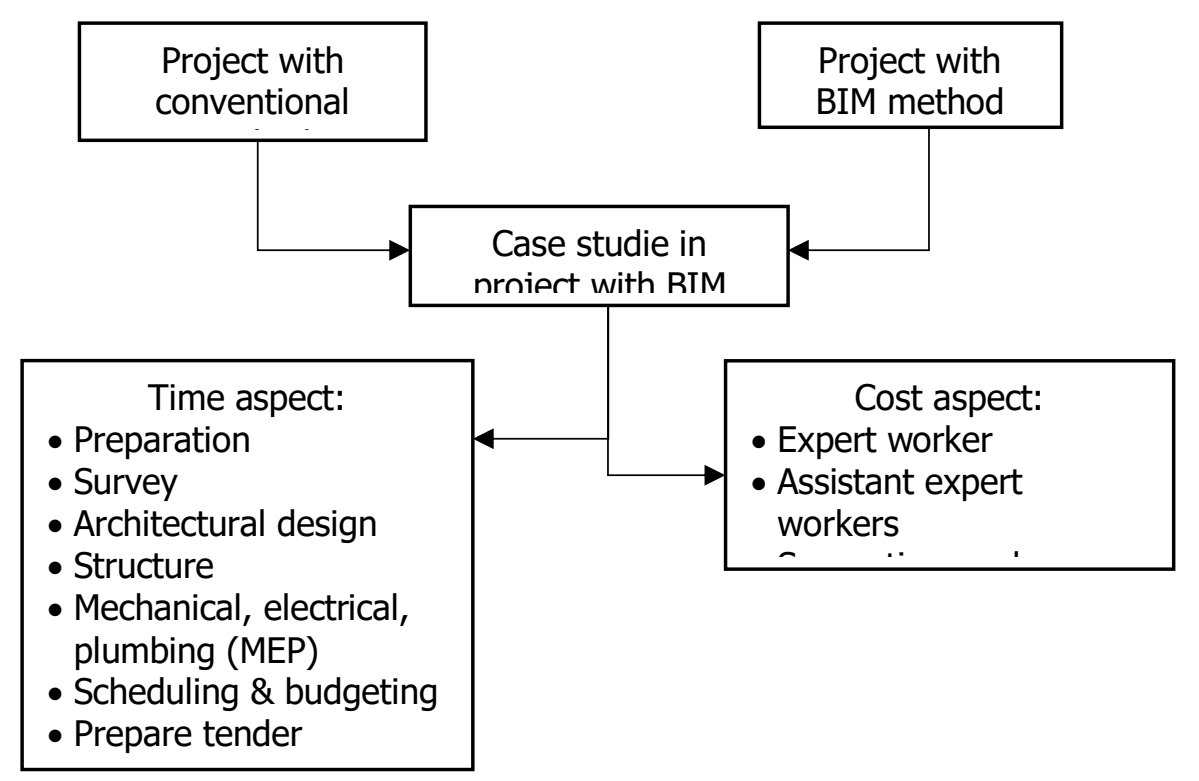

Fig. 1. The research framework analyzes the effect of BIM on time-costs

Based on Figure 1, it can be illustrated that this research conducted a case study by comparing projects without and with BIM. There are seven aspects of time analysis starting from preparation to preparing tender documents[15]. While the aspects of cost analysis are the costs of expert workers, expert assistant workers, supporting workers[16]. The investment costs of software and tools for BIM are not included because this research focuses on worker costs.

Analysis of the results of the questionnaire and interviews were carried out with quantitative and qualitative analysis. Quantitative analysis on aspects of time to calculate the 
duration of work between conventional and using BIM. In the aspect of costs to calculate the cost needs of the two methods which are then compared to the percentage reduction. While qualitative analysis to explain the origin before the calculation and why the results of such a calculation[17].

\section{Results and Discussion}

The advantage of BIM that can be seen in the questionnaire answers from respondents is that it makes it easier to reduce revisions to project planning because by using the BIM method errors in planning can be found at the beginning. This also helps avoid mistakes during implementation. BIM also facilitates coordination between contractors and sub-contractors, this is because coordination through BIM can be done using the BIM application connected via the internet where project stakeholders can access planning data and provide corrections if needed. BIM is also able to minimize the cost of mockups.

However, it can also be seen that BIM's shortcomings are that they must have extra skills or be able to master multiple multi-disciplines so that the use of the BIM application becomes more maximal. BIM applications require high hardware specifications. BIM applications are also less able to work with the maximum quality for images that are quite detailed. The most influential thing about the lack of use of the BIM application in Indonesia is the large investment costs needed to purchase one BIM application license unit.

\subsection{Comparison of the cost of conventional and BIM methods in case studies}

In a life cycle project, the use of conventional methods takes longer than BIM. This is because the conventional method between design, structure, and mechanical, electrical, plumbing (MEP) cannot be done simultaneously. Whereas the BIM between design, structure, and MEP can be done together to speed up planning because there is no need to wait for either party to finish first.

Table 1. The difference in project life cycle time in conventional and BIM methods

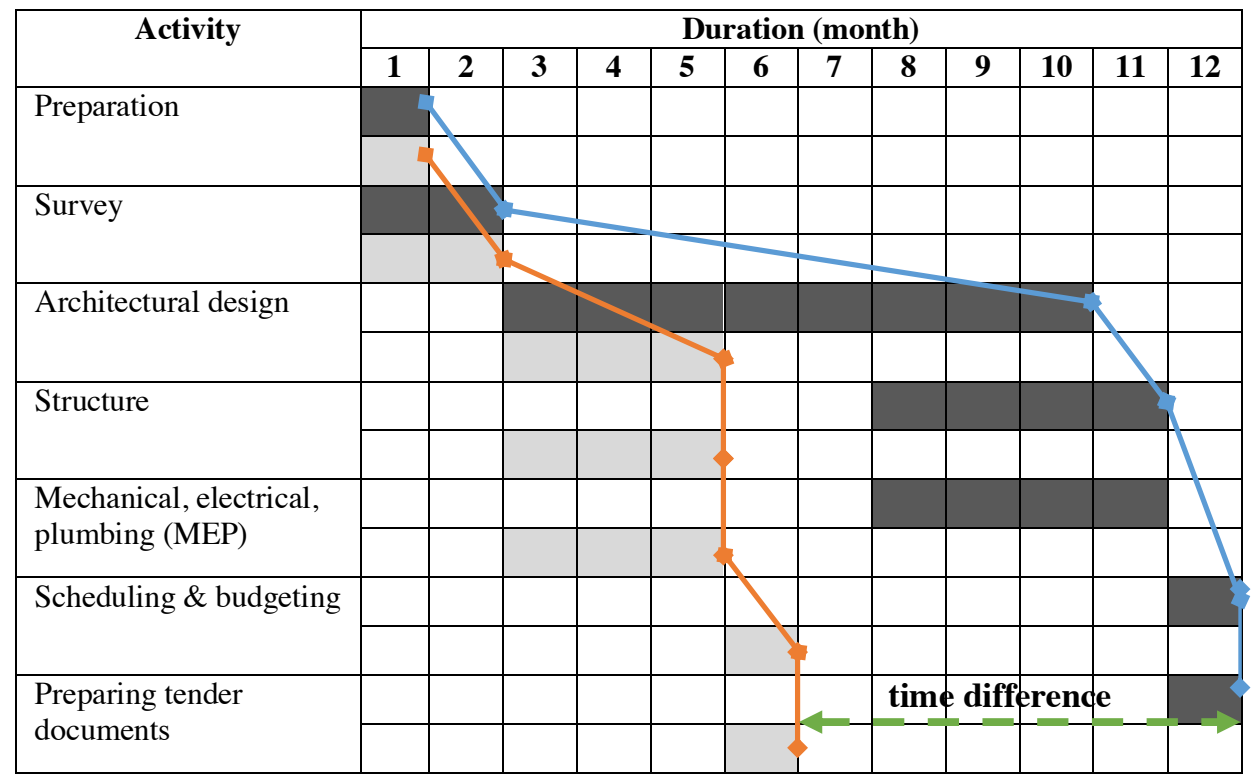


Based on Table 1, it can be seen how long the planning time is between conventional methods and BIM. The time required for planning using BIM is 50\% faster than planning using conventional methods. The most significant time reductions occur in architectural, structural, and MEP design activities. This is due to the use of BIM technology capable of accelerating these activities. BIM if done by skilled workers will succeed in ensuring accurate design and calculation. Similar research as conducted by Isaac, et al[18] on mapping the design of structures with BIM with a minimal interface that has many advantages in speed of performance. So if there is a correction, the system will change faster. This is different if the design and calculation by manual then the correction if there are errors, will take longer. Insignificant or equal duration changes in preparation, surveying, scheduling and budgeting activities, and preparing tender documents.

\subsection{Comparison of the cost of conventional and BIM methods in case studies}

Comparison of costs between conventional methods and BIM-based on the results of interviews with respondents about the needs of human resources to find out the comparison of labor costs required between conventional methods and BIM. The use of the BIM application in project planning can minimize the cost of expenditure. Cost calculation data regarding the years of worker's experience and time off work were obtained through interviews with respondents, while the unit price of wages was used as the unit price of work applicable in the project area. Following is a table regarding the comparison of personnel wage costs between conventional methods and BIM methods.

Table 2. Costs of conventional methods workers

\begin{tabular}{|c|c|c|c|c|c|c|}
\hline No & Position & People & $\begin{array}{c}\text { Time } \\
\text { (month) }\end{array}$ & $\begin{array}{c}\text { People } \\
\text { time }\end{array}$ & $\begin{array}{c}\text { Unit price } \\
\text { (in million } \\
\text { IDR) }\end{array}$ & $\begin{array}{c}\text { Cost } \\
\text { (in million } \\
\text { IDR) }\end{array}$ \\
\hline (1) & (2) & (3) & (4) & $(3) x(4)$ & (5) & (6) \\
\hline $\mathrm{A}$ & \multicolumn{6}{|l|}{ Expert worker } \\
\hline 1 & Team leader & 1 & 12 & 12 & 24.250 & 291.000 \\
\hline 2 & $\begin{array}{l}\text { Geotechnical } \\
\text { engineering }\end{array}$ & 1 & 2 & 2 & 16.750 & 33.500 \\
\hline 3 & Surveyor & 1 & 2 & 2 & 13.750 & 27.500 \\
\hline 4 & Architect & 1 & 8 & 8 & 16.750 & 134.000 \\
\hline 5 & Cost estimator & 1 & 1 & 1 & 13.750 & 13.750 \\
\hline 6 & Structure & 1 & 4 & 4 & 16.750 & 67.000 \\
\hline 7 & MEP & 1 & 4 & 4 & 16.750 & 67.000 \\
\hline $\mathrm{B}$ & \multicolumn{6}{|c|}{ Assistant expert workers } \\
\hline 1 & Assistant surveyor & 1 & 2 & 2 & 2.523 & 5.046 \\
\hline 2 & $\begin{array}{l}\text { Architect expert } \\
\text { assistant }\end{array}$ & 2 & 8 & 16 & 2.523 & 40.368 \\
\hline 3 & $\begin{array}{l}\text { MEP expert } \\
\text { assistant }\end{array}$ & 2 & 4 & 8 & 2.523 & 20.184 \\
\hline $\mathrm{C}$ & \multicolumn{6}{|l|}{ Supporting workers } \\
\hline 1 & Administration & 1 & 12 & 12 & 1.500 & 18.000 \\
\hline 2 & Drafter & 2 & 11 & 22 & 1.500 & 33.000 \\
\hline & & & & & Total cost & 750.348 \\
\hline
\end{tabular}


Table 3. Costs of BIM methods workers

\begin{tabular}{|c|c|c|c|c|c|c|}
\hline No & Position & People & $\begin{array}{c}\text { Time } \\
\text { (month) }\end{array}$ & $\begin{array}{c}\text { People } \\
\text { time }\end{array}$ & $\begin{array}{c}\text { Unit price } \\
\text { (in million } \\
\text { IDR) }\end{array}$ & $\begin{array}{c}\text { Cost } \\
\text { (in million } \\
\text { IDR) }\end{array}$ \\
\hline (1) & (2) & (3) & (4) & $(3) \times(4)$ & $(5)$ & (6) \\
\hline $\mathrm{A}$ & \multicolumn{6}{|l|}{ Expert worker } \\
\hline 1 & BIM experts & 1 & 6 & 6 & 24.250 & 145.500 \\
\hline 2 & $\begin{array}{l}\text { Geotechnical } \\
\text { engineering }\end{array}$ & 1 & 2 & 2 & 16.750 & 33.500 \\
\hline 3 & Surveyor & 1 & 2 & 2 & 13.750 & 27.500 \\
\hline 4 & Cost estimator & 1 & 1 & 1 & 13.750 & 13.750 \\
\hline 5 & Structure & 1 & 3 & 3 & 16.750 & 50.250 \\
\hline 6 & MEP & 1 & 3 & 3 & 16.750 & 50.250 \\
\hline $\mathrm{B}$ & \multicolumn{6}{|c|}{ Assistant expert workers } \\
\hline 1 & Assistant surveyor & 1 & 2 & 2 & 2.523 & 5.046 \\
\hline 2 & $\begin{array}{l}\text { Architect expert } \\
\text { assistant }\end{array}$ & 1 & 3 & 3 & 2.523 & 7.569 \\
\hline 3 & MEP expert assistant & 1 & 3 & 3 & 2.523 & 7.569 \\
\hline $\mathrm{C}$ & \multicolumn{6}{|l|}{ Supporting workers } \\
\hline 1 & Administration & 1 & 6 & 6 & 1.500 & 9.000 \\
\hline 2 & Drafter & 1 & 5 & 5 & 1.500 & 7.500 \\
\hline
\end{tabular}

The difference in cost between the use of conventional applications with BIM in project planning, where the use of BIM applications compared to the use of conventional applications in planning can reduce costs by $52.36 \%$. This figure is obtained from a comparison between the difference between the amount of BIM and conventional costs and the total cost when using conventional methods. The big difference in cost between BIM and conventional applications is because of several experts and time. The number of experts required in the use of BIM is less than the conventional application user expertise. The time required between planning using BIM is only 6 months, while planning using conventional applications takes 12 months, so the costs incurred by conventional application users are greater because it requires more planning time. As a note, the cost calculation in this study does not include investment in BIM software. This is because there will be differences in variables between the two methods. BIM software investment in construction projects is a large capital but will also have a major impact on the effectiveness and efficiency of project performance[19].

\subsection{The advantages and disadvantages of BIM}

Based on questionnaires and case study interviews can be obtained the advantages and disadvantages of BIM application. The advantages of BIM are software integration, collision detection design, faster processing, saving resources, and costs. In projects that use conventional applications usually use a lot of software such as for the analysis of the strength of the structure, software for design and drawing, software for calculating volumes, and scheduling. However, by using BIM software, all these needs can be accommodated in one software that can be done by one person only because of the integration of some other software that is needed. The design collision occurs because of a mismatch between the architect's design, the structure, and the MEP, in BIM it can be avoided by crash detection 
from the BIM software[20]. It also reduces design revisions and errors that occur when construction starts.

While the lack of BIM is the high price of a license. A large hardware specification is required so that the application with the BIM concept works well it requires a minimum of 16GB RAM, and a minimum NVIDIA Quadro Series graphics card or the like. BIM is less able to detail images with a fairly small scale optimally. Therefore, depictions with a scale below 1:20 still require images using AutoCAD

\section{Conclusions}

The challenge to reduce the time and cost of construction projects will always occur throughout the project. Integrated management is needed in answering these challenges. Utilization of Building Information Modeling (BIM) is expected to be a solutive answer. The results of research with a case study in a construction project stated that the use of BIM can reduce work time by up to $50 \%$. While costs can be reduced by $52.36 \%$. A good result when compared with conventional methods. The main factor of the large time-cost reduction caused by the use of BIM technology is accelerating the design process and structure calculation. Besides, the number of workers' needs is also less because skilled workers can work more optimally with BIM software. This study also analyzed the advantages and disadvantages of BIM which can be used as literature for construction projects especially in Indonesia.

This research is still limited to time in general in the project life cycle so that it can be developed into detailed design work or structural calculations for example. Besides, more case studies can also be developed to find out the characteristics of the type of construction work, because this research is still focused on buildings.

\section{References}

[1] X. Li, P. Wu, X. Wang, and Y. Teng, "Automation in Construction Mapping the knowledge domains of Building Information Modeling ( BIM ): A bibliometric approach," Autom. Constr., vol. 84, no. July, pp. 195-206, (2017).

[2] Y. Lu, Z. Wu, R. Chang, and Y. Li, "Automation in Construction Building Information Modeling ( BIM ) for green buildings : A critical review and future directions," Autom. Constr., vol. 83, no. February, pp. 134-148, (2017).

[3] M. N. Sholeh, A. Nurdiana, B. Setiabudi, and Suharjono, "Identification of Potential Uses of Building Information Modeling (BIM) for Construction Supply Chain Management: Preliminary Studies," IOP Conf. Ser. Earth Environ. Sci., vol. 448, (2020).

[4] L. P. Luong, C. Amin, and D. Thien-my, "BIM contributions to construction supply chain management trends : an exploratory study in Canada," Int. J. Constr. Manag., pp. 1-19, (2019).

[5] J. Irizarry, E. P. Karan, and F. Jalaei, "Integrating BIM and GIS to improve the visual monitoring of construction supply chain management," Autom. Constr., vol. 31, pp. 241-254, (2013).

[6] E. P. Karan, J. Irizarry, and J. Haymaker, "BIM and GIS Integration and Interoperability Based on Semantic Web Technology," J. Comput. Civ. Eng., vol. 30, no. 3, p. 04015043, (2016).

[7] X. Liu, X. Wang, G. Wright, J. C. P. Cheng, X. Li, and R. Liu, “A State-of-the-Art Review on the Integration of Building Information Modeling (BIM) and Geographic Information System (GIS)," ISPRS Int. J. Geo-Information, vol. 6, no. 2, p. 53, (2017). 
[8] S. L. Chan and M. Park, "Project cost estimation using principal component regression," Constr. Manag. Econ., vol. 23, no. 3, (2005).

[9] M. M. Tahir, N. A. Haron, A. H. Alias, A. N. Harun, and I. B. Muhammad, "Improving Cost and Time Control in Construction Using Building Information Model (BIM): A Review," Pertanika J. Sci. Technol., vol. 26, no. 1, (2018).

[10] M. A. Wibowo, N. U. Handayani, A. Nurdiana, and M. N. Sholeh, "The identification of waste construction at construction project life cycle," Adv. Sci. Lett., vol. 23, no. 3 , pp. 2633-2635, (2017).

[11] I. Mahamid, "Risk matrix for factors affecting time delay in road construction projects: owners' perspective," Eng. Constr. Archit. Manag., vol. 18, no. 6, pp. 609-617, (2011).

[12] P. F. Kaming, P. O. Olomolaiye, G. D. Holt, and F. C. Harris, "Factors influencing construction time and cost overruns on high-rise projects in Indonesia," Constr. Manag. Econ., vol. 15, no. 1, pp. 83-94, (1997).

[13] N. N. K. N. M. A. Azman, A. C. Ahmad, M. M. Derus, and I. F. M. Kamar, "Determination of Direct to Indirect Accident Cost Ratio for Railway Construction Project," MATEC Web Conf., vol. 266, (2019).

[14] D. F. Heathfield, An introduction to cost and production functions. Macmillan International Higher Education, (2016).

[15] M. Brook, Estimating and tendering for construction work. Taylor \& Francis, (2016).

[16] R. Aird, "The case for specialist training for learning support assistants employed in schools for children with severe, profound and multiple learning difficulties," Support Learn., vol. 15, no. 3, pp. 106-110, (2000).

[17] M. R. Hallowell and J. A. Gambatese, "Qualitative Research : Application of the Delphi Method to CEM Research," vol. 136, no. 1, pp. 99-107, (2010).

[18] S. Isaac, M. Curreli, and Y. Stoliar, "Work packaging with BIM.," Autom. Constr., vol. 83, pp. 121-133, (2017).

[19] R. Jin, C. M. Hancock, L. Tang, and D. Wanatowski, "BIM Investment, Returns, and Risks in China's AEC Industries," J. Constr. Eng. Manag., vol. 143, no. 12, p. 04017089, (2017).

[20] R. Deutsch, BIM and integrated design: strategies for architectural practice. John Wiley \& Sons, (2011). 